\title{
LINNUT HARRASTUKSEN JA TIETEEN KOHTEINA
}

\author{
OLAVI HILDÉN, JUHA TIAINEN \\ ja RISTO VALJAKKA (toim.): \\ Muuttolinnut. Kirjayhtymä, Helsin- \\ ki 1979.
}

Vuonna 1954 ilmestyneessä lintukirjassa "A Field Guide to the Birds of Britain and Europe" on mottona (osoitettuna "to our long-suffering wives") lause Shakespearen näytelmästä Windsorin iloiset rouvat: "She laments, sir, ... her husband goes this morning a-birding."

Biologisen tutkimuksen rinnalla elää ja menestyy laaja harrastustoiminta. Ilmiö on vanha; vaikkapa Huxleyn Elämän kontrapunktista tunnemme brittiläiset lordi-luonnontutkijat. Luonnon harrastaminen on leviämässä, tästä voi vakuuttua nähdessään kevätsunnuntaiden sankat retkeilijäjoukot minkä tahansa asutuskeskuksen liepeillä.

Ornitologinen kenttäharrastus maassamme koki ensimmäisen voimakkaan laajenemisvaiheensa 50 luvun alkupuolelta lähtien. Nykyisin harrastus on järjestäytynyttä: Lintutieteellisiä yhdistyksiä toimii maan eri osissa, ja niitä yhdistää valtakunnallinen liitto. Harrastusta pyritään koordinoimaan siten, että havaintoaineistoa kertyisi tiettyjen tutkimusongelmien ratkaisuun.

Muuttolinnut -kirja tuo tämän piirteen hyvin esiin. Kirjan tekstistä ja tiedoista vyöryvät esiin laajojen lintuharrastajajoukkojen retkeilytuntien tulokset. Kirjaan sisältyy 15 jaksoa, jotka kattavat aihepiirin eri puolet muuton tutkimuksen historiasta muuton fysiologiaan ja kevätja syysmuuton aikataulusta muuton evoluutioon. Eri jaksot sijoittuvat harrastus-tiede-jännitteen eri osiin. Tekstissä tämän erottaa ennen muuta käsittelytyylistä. Lähellä ornitologista kenttäharrastusta olevat jaksot ovat puhtaasti kuvailevia, jatkumon toiseen laitaan sijoittuvissa on analyyttisempi, lintujen muuton biologisista ongelmista jäsentyvä käsittelyote.

Mielenkiintoiseksi Muuttolinnut -kirjan tekee juuri harrastuksen ja tutkimuksen yhteyksien ja eron ilmeneminen yksien kansien vălissă.
$\mathrm{Ne}$ on toki pidettävă erillään, kyse on eri asioista.

Harrastuksen perisynteihin kuuluu erittelemätön havainnointi, keräily ja erikoisuuksien metsästys. Havainto on "hyvä", jos se koskee harvinaista lajia tai poikkeuksellisen suuria yksilömääriä. Mielekkäiksi havainnot tulevat kuitenkin vasta yhdistettyinä, jonkin tutkimusongelman mukaan jäsennettyinä, jolloin mukaan tulee suuri määrä tavallisia lajeja ja tavanomaisia yksilömääriä koskevia havaintoja. Havaintojen keruu sinänsä ei nosta esiin edes niitä ongelmia, joiden selvittämisessä havaintoaineisto voi auttaa.

Toinen harrastuksen perisynti on tieteellisten ongelmien sivuuttuminen. Ilmiötä pidetään selitettynä, kun se on saatu kuvatuksi. Kuvaaminen on kuitenkin vasta ensimmäinen edellytys vaikkapa lintujen muuton selittämiselle. Biologisia tutkimusongelmia jäsentävä keskeinen tekijä on darwinistinen evoluutioteoria. Muuttolinnut-kirjassa evoluutioteoria on tarkasteltavana muuton evoluutiota käsittelevässä jaksossa, mutta muuten sitä sivutaan tarpeettoman vähän. Kirjan koko profiilissa korostuu kuvaileva, kenttäharrastuksen elämyksistä ja havainnoista nouseva käsittelytapa, jonka taakse lintujen muutto biologisena ongelmana uhkaa peittyä. Kuitenkin biologisessa tutkimuksessa on parin viime vuosikymmenen aikana kehitetty runsaasti teoreettisia ideoita, jotka jäsentävät myös lintujen muuton tutkimusta. Näiden esittelyn puuttuminen on Muuttolinnut-kirjan olennainen heikkous.

Biologia on luonnontieteistä epäilemättä erityisasemassa siinä, että harrastuksen kautta kerätyillä havainnoilla on tieteen kehitykselle hyvin suuri merkitys. Kemian ja fysiikan tutkimuskohteet ovat pysyviä ja toistensa kaltaisia - yhtä vetyatomia tai rikkihappomolekyyliä ei voi erottaa toisesta. Elollisessa luonnossa olennainen piirre on moninaisuus, jonka hallitsemisen ensimmäinen ehto on riittävän suuren aineiston kokoaminen. Laaja harrastustoiminta on melkoinen voima tutkittaessa sellaisia ilmiöitä, joista tarvitaan runsasta, eri alueilta samanaikaisesti koottavaa havaintoaineistoa.

Harrastus voi biologiassa siis tuottaa korvaamatonta aineistoa tutkimuksen tueksi, mutta tämä edellyttää sen tutkimuksellista suuntaamista. On myös tarpeen muistaa, että biologia tieteenä alkaa kehittyä vasta sitten, kun havaintoaineisto on olemassa, ilmiöiden kartoitus on suoritettu.

Harrastus painottuu Muuttolinnuissa enemmän kuin tutkimus. Ehkä tämä on ollut myös kustantajan toivomus; kirjaa mainostetaan "luku- ja katselukirjana", siihen on myynnin lisäämiseksi ja hinnan kohottamiseksi ympätty värikuvasivuja, jotka ovat muusta sisällöstä jokseenkin irrallisia. Mutta kuten luonnonharrastus on viehättävää, on harrastukseen nojautuva hyvin kirjoitettu ja aiheensa hallitseva kirja myős viehättävä.

Yrjö Haila 